Egyptian Journal of Aquatic Biology \& Fisheries

Zoology Department, Faculty of Science,

Ain Shams University, Cairo, Egypt.

ISSN $1110-6131$

Vol. 25(5): 1017 - 1032 (2021)

www.ejabf.journals.ekb.eg

\title{
Salvatoria aegyptia n. sp. (Annelida, Syllidae) from El Ataka wharf, Suez Gulf (Egypt)
}

\section{Faiza Ali Abd Elnaby ${ }^{*}$, Guillermo San Martín²}

1-National Institute of Oceanography and Fisheries (NIOF), Qayet Bey, Alexandria, Egypt

2- Centro de Investigación en Biodiversidad y Cambio Global (CIBC-UAM) \& Departamento de Biología (Zoología), Facultad de Ciencias, Universidad Autónoma de Madrid, Canto Blanco, 28049 Madrid, Spain. https://0000-0002-8360-6221

*Corresponding Author: faiza_abdelnaby@yahoo.com

ARTICLE INFO

Article History:

Received: Nov. 14, 2021

Accepted: Nov. 26, 2021

Online: Dec. 11, 2021

Keywords:

Taxonomy,

Description,

New species,

Red Sea

\section{INTRODUCTION}

A new species of the genus Salvatoria McIntosh, 1885 (Annelida, Syllidae) was detected during a fouling collection on the hard substrates of the Wharf of El Akaba in the Suez Gulf. On the $5^{\text {th }}$ of Jan, 2021, a holotype and 8 paratypes were collected using a metal frame with an attached cone net. Samples were subjected to examinations under a stereomicroscope and identified to species level under an Olympus microscope. Scanning electron micrographs were taken and examined. Descriptions of the new species were determined. Results showed that this species has spindle-shaped dorsal cirri and antennae, pointed, oval pharyngeal tooth located on the anterior margin of the pharynx, and compound chaetae with elongated, bidentate blades, with teeth well separated from each other, and fine spines on the margin. The most similar species to the Egyptian species is Salvatoria nitiduloides, Nascimento et al., 2021 from Brazil. However, the Egyptian species has the pharyngeal tooth more anteriorly located, and the dorsoventral gradation in the length of blades is less marked than in the Brazilian species, especially on posterior segments. The holotype and a paratype of the new species were deposited in the collection of (TBAB 853) Lab. Of Oceanography \& Fisheries, Alexandria branch, Egypt. It was recorded as Salvatoria aegyptia n. sp, with reference to Egypt where it was found. This research would enrich the aquatic literature by adding useful data and recording a newly identified species to benefit scientists and researchers interested in this field.

Marine Annelids are helpful bio-indicators and provide accurate indications for adjusting aquatic conditions (Mieszkowska et $\boldsymbol{a l}$., 2013). Most records of new species have been found accidentally while working in other researches. The "ad hoc" studies conducted on the alien and indigenous fauna and flora receive low financial support, a state which makes the description of new species common and gives it a high priority (Lezzi, 2017). The family Syllidae (Grube, 1850) is well known for its large number of taxa (San Martin, 1984b). It is a highly diverse family with 97 genera and ca.1100 
species. The afore- mentioned family, including its genera and species are worldly reported having a very difficult taxonomy (Aguado et al., 2007; Pamungkas et al., 2019; Read \& Fauchald, 2020; Martin et al., 2021). San Martín and Aguado (2014) recognized 77 valid genera and around 964 species. The afore- mentioned recorded number increased to 993 (Pamungkas et al., 2019), and over 1100 currently accepted species were assessed (Daniel et al., 2021). Based on morphological and molecular analysis, Syllidae is currently divided into five subfamilies (Aguado et al., 2012; San Martin \& Aguado, 2014).

Among the Syllidae, the subfamily Exogoninae has the smallest species, most of which are interstitial, including nine genera: Brania Quatrefages, 1866 (Cicese DíazCastañeda \& San Martín, 2001), Erinaceusyllis San Martín, 2005, Exogone Ørsted, 1845, Parapionosyllis Fauvel, 1923, Parexogone Mesnil and Caullery, 1918, Prosphaerosyllis San Martín, 1984a, Salvatoria McIntosh, 1885 and Spherosyllis Claparède, 1863 (San Martín \&Aguado, 2014).

Salvatoria is a worldwide distributed genus, currently composed of about 32 valid species. In Egypt, specifically in the Mediterranean Egyptian coast, only four species of this genus were previously recorded, including S. euritmica (Sardá, 1984), S. vieitezi (San Martín, 1984b), S. clavata (Claparède, 1863) and S. limbata (Claparède, 1868) (Abd Elnaby \& San Martin, 2010; Hamdy \& Ibrahim, 2019). The specimens of the new species of Salvatoria herein described were collected on the Ataka dock, Suez Gulf, within a fouling collection.

Many benthic studies considered the Suez Gulf (Por, 1978; Safriel \& Lipkin, 1975; Ben-Eliahu, 1972; Amoureux et al., 1978). El-Komi (1996) estimated the distribution of macrobenthic communities along the eastern coast of the Suez Gulf. Belal (1995, 2001) studied the distribution of benthic animal's communities in the northern part of the Suez Gulf. El-Komi (1997), El-Komi and Beltagy (1997), El- Komi and Emara (2008) and El-Komi et al. (2002) studied the distribution of the macro benthos assemblages in the shallow intertidal zone along the western coast of the Suez Gulf. Belal and Ghobashy (2014) studied the macro-benthic invertebrates in each side of the Suez Gulf. Abd Elnaby (2019) studied polychaetes from Gabel El-Zeit, Suez Gulf.

Other studies, particularly of ecology, biology and economic importance include those of Hassan (1983), Ismail (2005), Gab-Allah et al. (2007), Radwan (2014) and El-Mekawy (2016). In the present study, the description of the new species were determined with remarks.

\section{MATERIALS AND METHODS}

In January, 2021, samples found on hard substrates of the wharf of El Ataka station, Suez Gulf (29 $58^{\prime} 37^{\prime \prime}$ N, 32 $31^{\circ} 18^{\prime \prime}$ E) were collected (Fig.1). This species was found within a fouling collection only in the station mentioned. Samples were collected by 
using a metal frame with a cone net attached. In the laboratory, samples were washed through $0.1 \mathrm{~mm}$ mesh sieve for small worms and $0.5 \mathrm{~mm}$ sieve for the rest of the fauna, and then fixed in $70 \%$ Ethyl alcohol. Specimens were sorted under a stereomicroscope model Optika, and then species were identified to species level under an Olympus CX21FS2 microscope. Photographs of some species were taken by a digital camera attached to the compound microscopes. SEM photos were taken by using a JEOL IT200 scanning electronmicros. For the SEM, specimens were first dehydrated in a graded series of increasing concentrations of ethanol (up to 100\%), followed by a critical point dehydration, and were then coated with gold and examined under the SEM. Drawings were added. Key for Salvatoria species for Egypt was added. The holotype and a paratype of the new species were deposited in the collection of Taxonomy and Biodiversity of Aquatic Biota (TBAB 853) Laboratory, National Institute of Oceanography and Fisheries, Alexandria branch, Egypt.

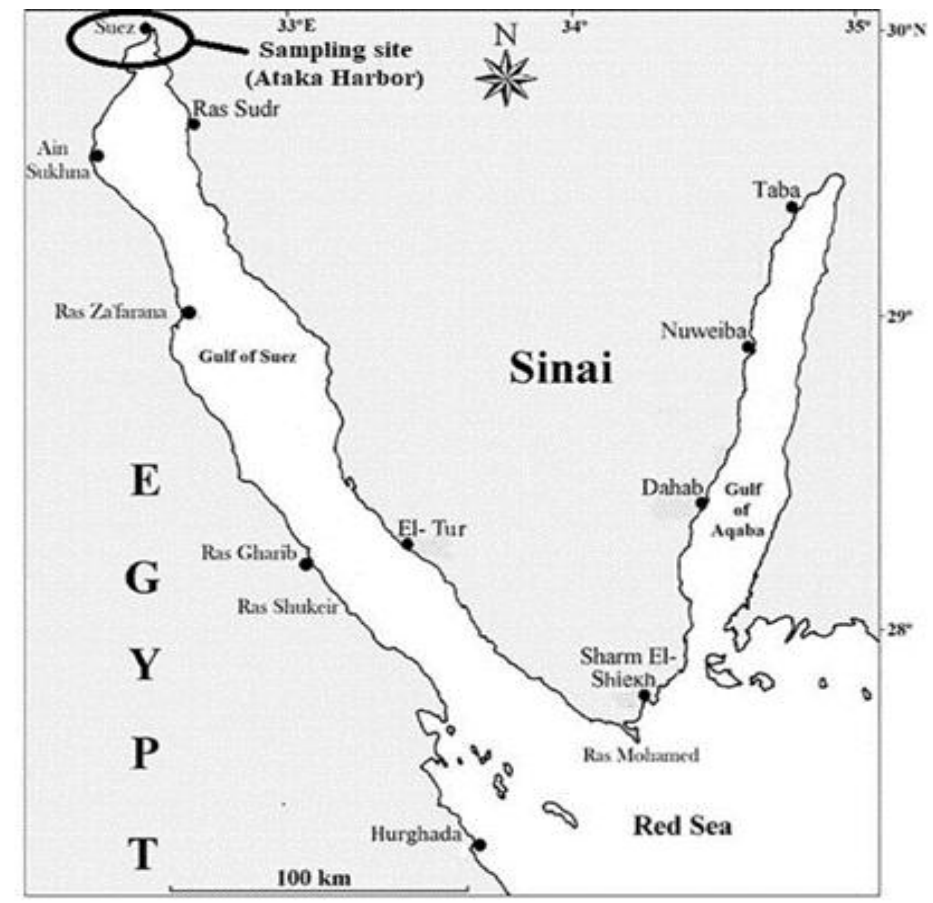

Fig. 1. A map showing the location of El Ataka port, in the Suez Gulf

\section{RESULTS}

Family Syllidae Grube, 1850

Subfamily Exogoninae Langerhans, 1879

Genus Salvatoria McIntosh, 1885

Salvatoria McIntosh, 1885: 188. San Martín (2003): 156; (2005): 49. Nascimento et al. (2021): 5 . 
Grubea Quatrefages, 1866: 19; San Martín,1984b: 150.

Brania (in part) Fauvel, 1923: 296; in part Kudenov \& Harris, 1995: 9.

Grubeosyllis Verrill, 1900: 633. San Martín (1991): 716.

Protogrubea Czerniavsky, 1881: 414.

Salvatoria aegyptia, sp. nov.

Figs. (2- 5)

\subsection{Material examined}

Holotype (TBAB 853) and eight paratypes were collected from the wharf of El Ataka station of Suez Gulf, (29 $58^{\prime} 37^{\prime \prime} N$, 32 $31^{\prime} 18^{\prime \prime}$ E), on the $5^{\text {th }}$ of January 2021 during a fouling collection.

\subsection{Description}

The body is small and delicate, up to $2.5 \mathrm{~mm}$ long, $0.20 \mathrm{~mm}$ wide, with $33-35$ chaetigers, and without color markings. Prostomium is ovate, wider than long and is partially covered posteriorly by peristomium; two pairs of eyes are set in trapezoidal arrangement. Palps are triangular, well developed, joined along their length by dorsal membrane, almost totally fused, leaving usually short notch (Figs. 2A, 3A, 4A). Antennae is spindle-shaped, slightly bulbous at their base and ending with an elongate, acute tip; median antenna is inserted between posterior pair of eyes, similar in length to prostomium and palps together; lateral antenna is slightly shorter than median antenna, inserted close to anterior eyes. Peristomium is slightly shorter than subsequent segments; dorsal tentacular cirri is similar to median antenna, while the ventral tentacular cirri is about 2/3 the length of the dorsal ones (Figs. 2A, 3A, 4A).

The parapodia are conical; The dorsal cirri are similar to the antennae and the tentacular cirri, but for those of chaetiger 1, they are longer than the remaining (Figs. 2A, $3 \mathrm{~A}, 4 \mathrm{~B}$ ), whereas those of chaetiger 2 and 3 are shorter, and the remaining dorsal cirri are alternatively irregular, varying between long and short. The ventral cirri digitiform are shorter than the parapodial lobes (Fig. 3A, 4A-B). The holotype of a mature female was found carrying dorsal eggs (Fig. 3B). Compound chaetae heterogomph falcigers are 7-9 and are found on the anterior parapodia (Figs. 2B, 3C , 4C), while, on midbody, they are reduced to 5-6 (Fig. 2D, 4D), but on the posterior parapodia, they are only 3-4 (Fig. 2F). The falcigers were detected with elongated, bidentate blades, and the teeth are slightly unequal, with a well separated space between teeth wide, and are distinctly concave. The examined blades have moderate, fine spines on the margin, and the spines are longer in the dorsal and the anterior chaetae. Furthermore, a marked dorso-ventral gradation was found with respect to the length of blades, with $25 \mu \mathrm{m}$ long above, and $13 \mu \mathrm{m}$ long below on the anterior parapodia (Figs. 2B, 3C, 4C), and $18 \mu \mathrm{m}$ long above and $11 \mu \mathrm{m}$ long below on the posterior parapodia (Fig. 2F). The posterior compound chaetae was noted with less marked differences in size and shape of blades (Figs. 2F). The dorsal simple chaetae are distinctly bidentate with short subdistal spines (Fig. 2E, 3D) and are present from 
chaetiger two. While, the ventral simple chaetae are similar to the dorsal ones, but shorter, sigmoid and thicker, and are only present in posterior-most parapodia (Fig. 2G). The anterior parapodia are found with two aciculae; one is straight, while the other is subdistally and slightly inflated, curved and acuminate with short tip (Figs. 2C, 3E); a single acicula per parapodium is found extending from midbody onwards, and is thicker towards the posterior body (Fig. 2H, 3F). Moreover, the pharynx is apparently without papillae around the opening; it is anteriorly wide and usually cup-shaped through four segments (Figs. 2A, 3A, G); the pharyngeal tooth is conical, slim and located on the anterior margin (Fig. 3G). In addition, the proventricle is similar in length to the pharynx, extending through four segments, with 18-20 muscle-cell rows (Figs. 2A, 3A). The pygidium is characterized with two short anal cirri detected in the holotype (Fig. $3 \mathrm{H}$ ). 


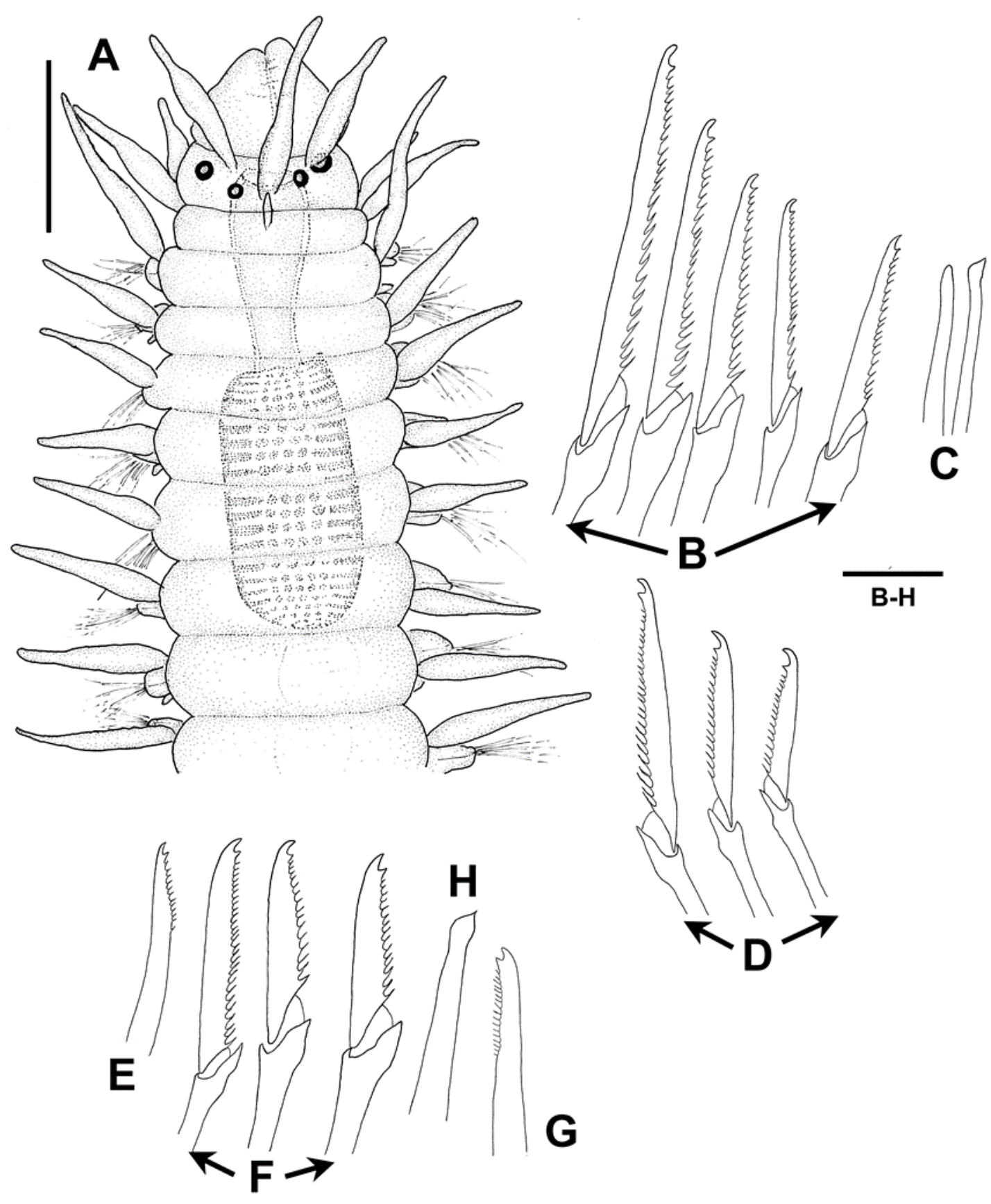

Fig. 2. The Salvatoria aegyptia n. sp. Holotype A: anterior end, dorsal view. B: compound chaetae, anterior parapodia. C: aciculae, anterior parapodia. D: compound chaetae, midbody. E: dorsal simple chaeta. F: compound chaetae, posterior parapodia. G: ventral simple chaeta. H: acicula, posterior parapodia. Scale.- A: $0.5 \mathrm{~mm}, \mathbf{B}-\mathbf{H}: 50 \mu \mathrm{m}$. 


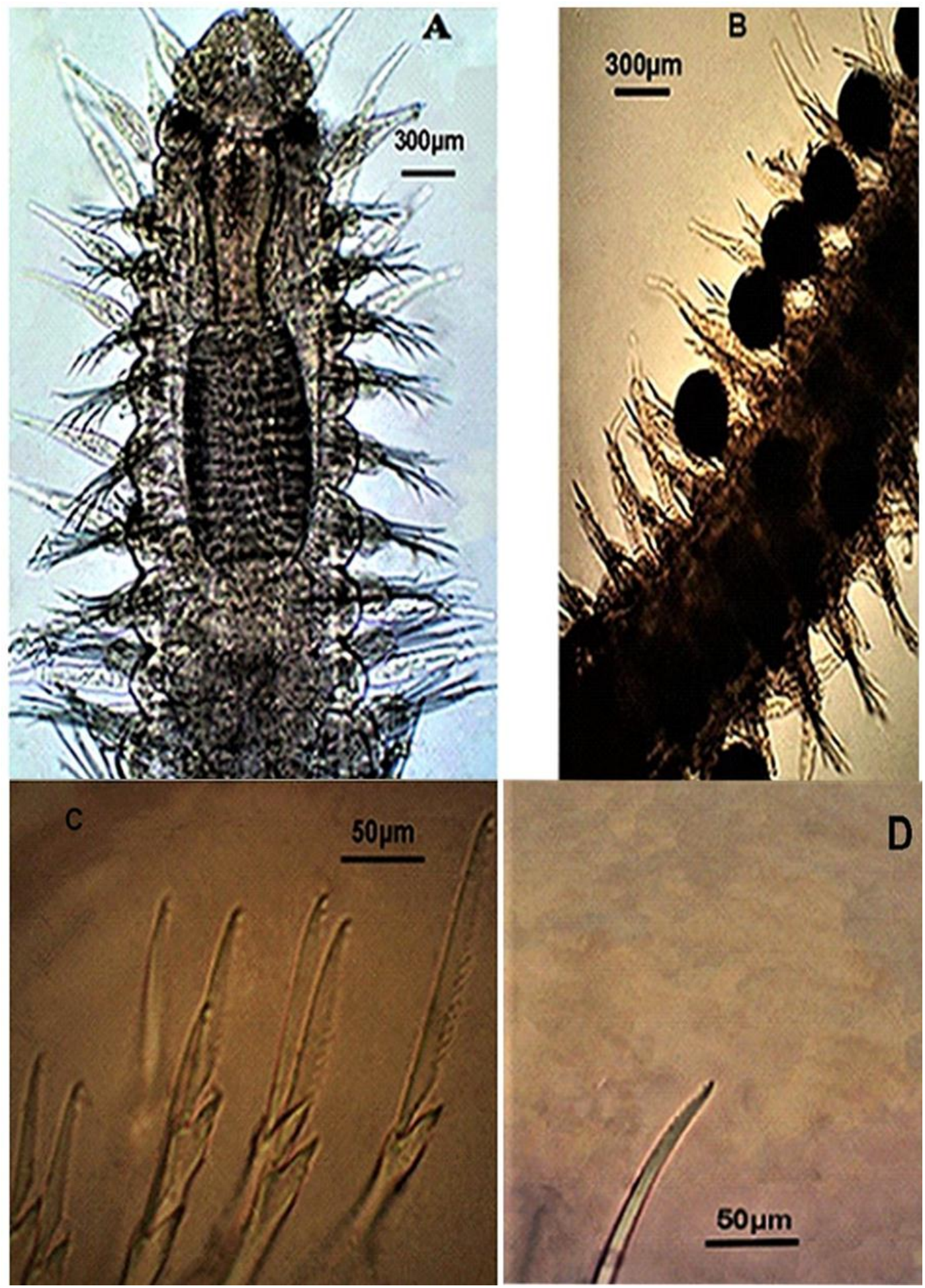



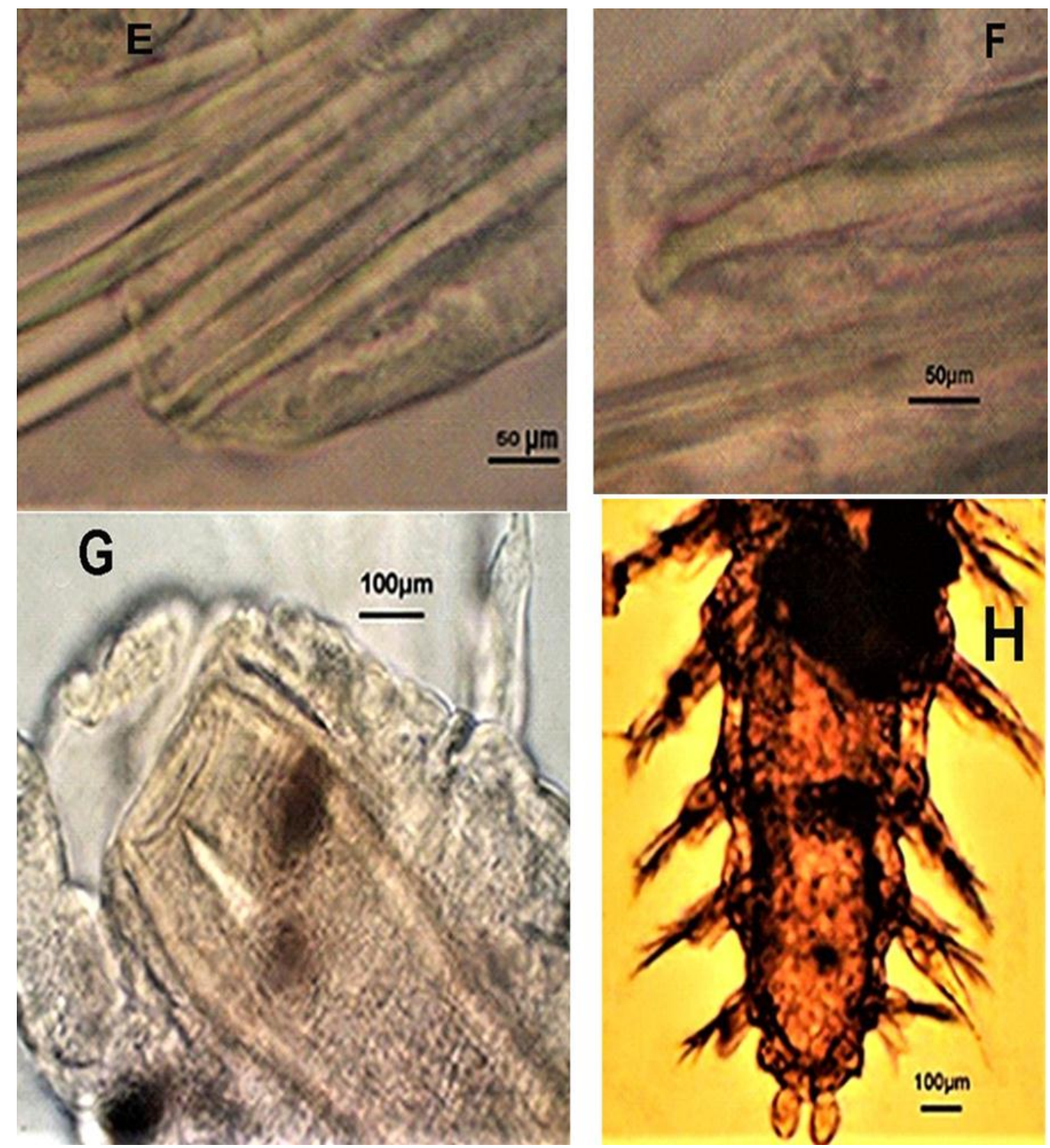

Fig. 3. Salvatoria aegyptia $\mathrm{n}$. sp. Holotype, exhibiting the light microscope photographs A: anterior end, ventral view. B: midbody, carrying eggs dorsally. C: compound chaetae, anterior parapodium. D: dorsal simple chaeta. E: aciculae, anterior parapodium. F: acicula, posterior parapodium. G: anterior end of pharynx, ventral view. H: posterior end, ventral view. Scale. A, B $300 \mu \mathrm{m}$. C, D $100 \mu \mathrm{m}$. E-H $50 \mu \mathrm{m}$. 

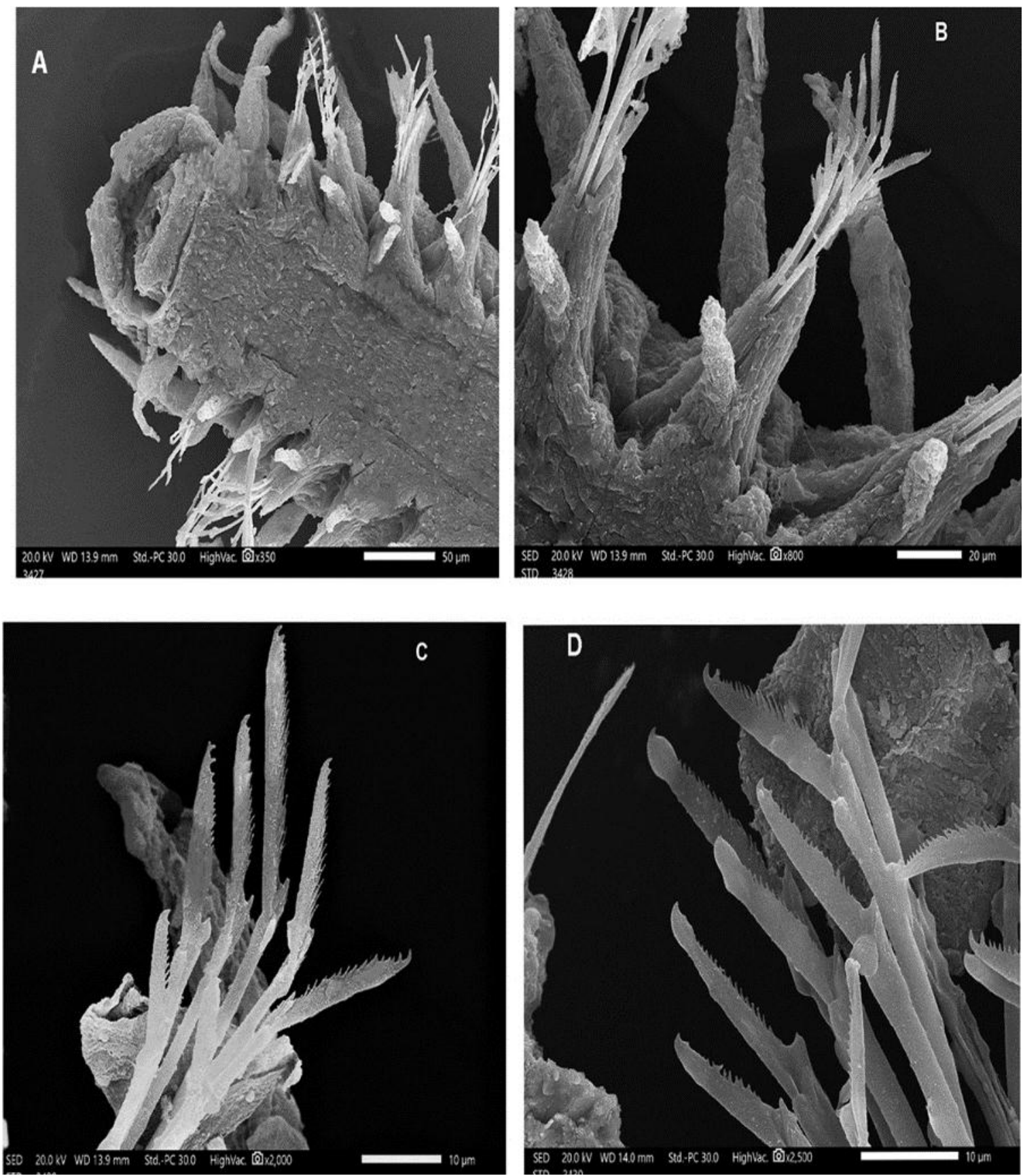

Fig. 4. The Salvatoria aegyptia n. sp., SEM A: anterior end, ventral view. B: mid body parapodia, ventral view. C: anterior body chaetae. D: mid body chaetae. Scale: A $50 \mu \mathrm{m}$. B $20 \mu \mathrm{m}$. C, D $10 \mu \mathrm{m}$. 


\section{DISCUSSION}

The most remarkable characteristic of the new species of Salvatoria is that the pharyngeal tooth is located on the anterior margin of the pharynx, and the compound chaetae have elongated blades on the anterior and the midbody parapodia, with both teeth separated, forming a rounded, concave space. The most similar species is S. nitiduloides (Nascimento et al., 2021) from Brazil. In comparison, the pharyngeal tooth in the Egyptian species is more anteriorly located, and the dorso-ventral gradation in the length of blades is less marked than in the Brazilian species (Nascimento et al., 2021). Despite that the body shape, the dorsal and the ventral simple chaetae, and the anterior compound chaetae are almost identical; the posterior chaetae of S. aegyptia sp. nov. have shorter blades, all of which are similar, whereas those of S. nitiduloides are similar to the anterior ones. Another detected difference is that the aciculae in S. nitiduloides seems to be more pointed, with longer tip.

Hartmann-Schröder (1960) described and reported other species of this genus (as Grubea Quatrefages, 1865) from the Red Sea (G. limbata Claparède, 1868; G. nuchalata Hartmann-Schröder, 1960, probably a member of Erinaceusyllis San Martín, 2003; G. gracilis Hartmann-Schröder, 1960; and G. balani Hartmann-Schröder, 1960; all these species differ clearly from $S$. aegyptia sp. nov. by the compound chaetae, acicula and dorsal simple chaetae. Blades of compound chaetae in G. balani are very short and bidentate. Long bidentate and unidentate; serrated and smooth blades present in $G$. limbata; acicula in both straight with pointed tip and subdistal swollen. Pharynx papillated in G. gracilis, unidentate chaetae and one acicula with rounded tip for each parapodia are present. G. nuchalata has papillated dorsal cirri and serrated unidentate chaetae. All previous characters indecated that all Grubea species described from the Red Sea by Hartmann-Schröder (1960) surely differ from the Salvatoria aegyptia sp. nov. collected from the wharf of El Ataka station, Suez Gulf.

Ben-Eliahu (1977) reported S. clavata from the Gulf of Eilat. Posterior compound chaetae of S. aegyptia sp. nov. are similar to those of $S$. clavata, but the anterior chaetae and midbody falcigers are different. S. aegyptia sp. nov. with anterior 7-9 chaetae; marked dorso-ventral gradation in length of blades, $25 \mu \mathrm{m}$ long above, $13 \mu \mathrm{m}$ long below on anterior parapodia and $18 \mu \mathrm{m}$ long above and $11 \mu \mathrm{m}$ long below on posterior parapodia different from Ben-Eliahu's specimens, she mentioned; ten long straight bidentate falcigers, and superior falcigers of midbody, $27 \mu \mathrm{m}$ long; inferior falcigers, $1.6 \mu \mathrm{m}$ long. In addition, the pharyngeal tooth in $S$. clavata is located more posteriorly in the pharynx. On the other hand, Salvatoria longiarticulata (Nogueira, San Martín and Amaral, 2001) from Brazil also has elongated and bidentate blades of compound chaetae, but a longer pharynx is observed with shorter proventricle, and both teeth of blades are close to each other (Nogueira et al., 2001). While,Salvatoria longisetosa (Hartmann-Schröder, 1979) from Australia has the pharyngeal tooth located in the middle of the pharynx and 
the compound chaetae have small teeth, close to each other (Hartmann-Schröder, 1979; San Martín 2005).

Finally, Salvatoria kerguelensis McIntosh, 1885 from the Kerguelen Islands, South Georgia, New Zealand and Australia, has a very similar body, but the pharyngeal tooth is located slightly away from to the pharyngeal opening and the compound chaetae have shorter blades (San Martín, 2005).

The Salvatoria aegyptia sp. nov. has median antenna inserted between the posterior pair of eyes, while the median antenna of Salvatoria nitidula (Verrill, 1900) is inserted between the anterior pair of eyes. The Salvatoria aegyptia sp. nov. is characterized with dorsal peristomial cirri similar to the median antenna; dorsal cirri from chaetiger 1 are longer than the remaining; those of chaetiger 2 and 3 are shorter, the remaining dorsal cirri are alternating irregularly long and short, while the dorsal cirri from chaetiger 1 are longer than the remaining in S. nitidula. Falciger blades of Salvatoria aegyptia sp. nov. are bidentate, the teeth are slightly unequal, and the lengths of the falciger blades are 25$13 \mu \mathrm{m}$ long and 18-11 $\mu \mathrm{m}$ long on the anterior and the posterior parapodia, respectively. Comparing with $S$. nitidula, falciger blades with distal tooth are larger than subdistal ones on anterior and midbody parapodia, while the teeth are about the same size on the posterior body, whereas the falciger blades are longer; 30-10 $\mu \mathrm{m}$ on anterior and midbody parapodia, respectively (Nascimento et al. 2021).

Etymology. The name of the species refers to Egypt, the country in which this species has been found.

\section{Key for the Salvatoria species recorded in Egyptian waters:}

1.- Compound chaetae with smooth, unidentate blades, except the most dorsal one or two, which are longer, with short basal spines and a small subdistal minute proximal tooth. Pharyngeal tooth located on anterior margin of pharynx..................... limbata

-- Compound chaetae bidentate. Pharyngeal tooth located on anterior margin or backwards in the pharynx......................................................

2.- Blades of compound chaetae strongly bidentate, with both teeth similar S. euritmica

.- Proximal tooth of blades smaller than distal one and close to the distal one.............3 3.- Pharyngeal tooth located distinctly away from the anterior margin. Blades of compound chaetae with similar morphology (with dorso-ventral gradation in length), with short spines on margin, S. clavata.

- Pharyngeal tooth located on anterior margin. Compound chaetae with different morphology anterior-posteriorly and/or dorso-ventrally $\ldots \ldots \ldots \ldots \ldots \ldots \ldots \ldots \ldots \ldots$

4.- Dorsal compound chaetae with long basal spines, distally dressed; remaining chaetae smaller and with short spines on margin. Anterior segments usually with transversal reddish bands S. vieitezi 
-- Compound chaetae of anterior segments with long, slender blades, with short to moderatebasal spines; remaining chaetae with blades shorter, with short spines on margin. Body without colour patterns S. aegyptia n. sp.

\section{REFERENCES}

Abd Elnaby, F. (2019). Polychaetes from Suez Gulf (Gabel El Zeit), Egypt. Egyp. J. Aqu. Biol and Fish., 23(5): 43- 53.

Abd Elnaby, F. and San Martín, G. (2010). Eusyllinae, Anoplosyllinae, and Exogoninae (Polychaeta: Syllidae) for the Mediterranean Coasts of Egypt, together the description of one new species. Life Sci. J., 7(4):132-139.

Aguado, M.T.; Nygren, A. and Siddall, M. E. (2007). Phylogeny of Syllidae (Polychaeta) based on combined molecular analysis of nuclear and mitochondrial genes. Cladis., 23: 552-564.

Aguado, M.; San Martín, G.; and Siddall, M.E. (2012). Systematics and evolution of syllids (Annelida, Syllidae). Cladis., 28: 234-250.

Amoureux, L.; Rullier, F. and Fishelson, L. (1978). Systématique et Ecologie d'Annélides Polychètes de la presqu'îl du Sinai. Isr. J. Zool., 27(2-3): 57-163.

Belal, A. A. (1995). Ecological studies on macrobenthic invertebrates, in the intertidal zone of the Suez region. M.Sc. Thesis, Faculty of Science Suez Canal University, 215 pp.

Belal, A. A. and Ghobashy, M. A. F. (2014). Macrobenthic Invertebrates in the Intertidal Zone at both Sides of the Suez Gulf. Internat. J. Mar. Sci., 4 (48): 1-11.

Belal, A. A. (2001). Ecological studies on the polychaetes in the Suez Bay. Ph.D. Thesis. Faculty of Science, Zagazig University, 295 pp.

Ben Eliahu, M. N. (1972). A description of Hydroides steinitzi n. sp. (Polychaeta: Serpulidae) from the Suez Canal with remarks on the serpulid fauna of the canal. Isr. J. Zool., 21: 77-81.

Ben-Eliahu, M. N. (1977). Polychaete Cryptofauna from Rims of Similar Intertidal Vermetid Reefs on the Mediterranean Coast of Israel and in the Gulf of Elat: Exogoninae and Autolytinae. Isr. J. Zool., 26: 1-58. 
Claparède, É. (1863). Beobachtungen über Anatomie und Entwicklungsgeschichte wirbelloser Thiere an der Küste von Normandie angestellt, 120 pp.

Claparède, É. (1868). Les annélides chétopodes du Golfe de Naples. Mém. de la Soci. de Phys. et d'Hist. Natur. de Genève. 19(2): 313-584, plates I-XVI., https://www.biodiversitylibrary.org/page/14309905

Czerniavsky, V. (1881). Materalia ad zoographiam Ponticam comparatam. Bull. de la Soc. Imper. de Cien. Natur., Mosc., 55: 213-363.

Daniel, M.; Aguado. M.; Álamo, M.; Britayev, T.; Böggemann, M.; Capa, M.; Faulwetter, S.; Fukuda, M.; Helm, C.; Petti, M.; Ravara, A. and Teixeira, M. (2021). On the Diversity of Phyllodocida (Annelida: Errantia), with a Focus on Glyceridae, Goniadidae, Nephtyidae, Polynoidae, Sphaerodoridae, Syllidae, and the Holoplanktonic Families. Divers., 13 (3):131. https://doi.org/10.3390/d13030131

Díaz-Castañeda, V. and San Martín, G. (2001). Syllidae (Polychaeta) from San Quintín Bay, Baja California, México, with descriptions of a new genus. Proceed. Biol. Soci. Wash., 114(3): 708-719.

El Komi, M. (1996). Coastal development and pollution impacts on the distribution of macrobenthic communities along the eastern coast of the Gulf of Suez (Egypt). Pakis. J. Mar. Sci., 5(1):1-13. http://aquaticcommons.org/17625/1/PJMS5.1_001.

El-Komi, M. M. (1997). Preliminary list to the summer macro benthos in the intertidal zone of the western Gulf of Suez. Bull. Inst. Oceanog. Fish., 23: 295-314.

El-Komi, M. M. and Beltagy A. I. (1997). Distribution of macrobenthos assembleges in the north coast of Egypt. Bull. Nat. Inst. Oceanog. Fish., ARE, 23: 267-293. http://www.niof.sci.eg/images/ejar/vol23/DISTRIBUTION\%20OF\%20MACRO\%20BE NTHOS\%20ASSEMBL4GES.

El-Komi, M.M.; Emara, A. M. and Mona, M.H. (2002). Hydrographical and conditions and benthic assemblages in Suez Gulf, Egypt. Pakis. J. Mar. Sci.,1:1-18. http://aquaticcommons.org/id/eprint/17803.

El Komi, M. and Emara, A. (2008). Benthos monitoring in Red Sea, Egypt A- The western coast of the Suez Gulf Egypt. J. Aqu. Biol. Fish., U, (A): 57 -79.

El-Mekawy, H. A. (2016). Biological studies on some intertidal bivalves (Mollusca) from the northern portion of the Suez Gulf, Egypt. M. Sc. Thesis, Faculty of Science AlAzhar University, Egypt, 243 pp. 
Fauvel, P. (1923). Faune de France 5. Polychètes Errantes, 486 pp. Paris: Le Chevalier Eds.

Gab-Alla, A. A.F.A.; Mohammed, S.Z.; Mahmoud, M.A.M. and Soliman, B.A. (2007). Ecological and biological studies on some economic bivalves in Suez Bay, Gulf of Suez, Red Sea, Egypt. J. of Fish. and Aqu. Sci., 2(3): 178-194.

Grube, A. E. (1850). Die Familien der Anneliden. Arch. für Naturg., Berl., 16: 249-364.

Hamdy, R. and Ibrahim, H.G. (2019). Recent changes in polychaete community along the Alexandria coast. Egypt. Egypt. J. of Aqu. Biol. and Fish., 23(1):1-12. DOI: 10.21608/ejabf.2019.25931

Hartmann-Schröder, G. (1960). Polychaeten aus dem Roten Meer. Kiel. Meeresforschungen, 16: 69-125.

Hartmann-Schröder, G. (1979). Teil 2. Die Polychaeten der tropischen Nordwestküste Australiens (Zwischen Port Samson in Norden und Port Hedland in Süden). Mitteil. aus dem Hamburg. Zool. Mus. Inst., 76: 75-218.

Hassan, A. K. (1983). Studies on the molluscan fauna of the Mediterranean and Red Seas and their exchange through the Suez Canal. Ph. Dissertation Cairo University, ARE. 367 pp. http:// zonatus.com/Killers\%20 cones. htm, 2014.

Ismail, I. M. (2005). Ecological and Biological studies on some intertidal Benthic communities in Suez Gulf, Red Sea, Egypt. M.Sc. thesis, zoology department, faculty of Science, Al-Azhar, 238 pp.

Kudenov, J. and Harris, L. (1995). Family Syllidae Grube, 1850. In: Taxonomic Atlas of Benthic Fauna of the Santa Maria Basin and Western Santa Barbara Channel, ed. J. Blake, B. Hilbig, \& P.H. Scott, pp. 1-97. Santa Barbara, California: Santa Barbara Museum of Natural History.

Langerhans, P. (1879). Die Würmfauna von Madeira. Zeitsch. für Wissenschaft. Zool., 33: 267-316.

Lezzi, M. (2017). Caulleriella mediterranea, a new species of polychaete (Annelida: Cirratulidae) from the central Mediterranean Sea. The Europ. Zool. J. 84: 1-10. http://www.tandfonline.com/doi/full/10.1080/24750263.2017.1343397

McIntosh, W.C. (1885). Report on the Annelida Polychaeta collected by H.M.S. Challenger during the years 1873-76. Challeng. Repor., 12: 1-554. 
Martin, D.; Aguado, M.T.; Fernández, M.A.; Britayev, T.A.; Böggemann, M. and Capa, M. (2021). On the Diversity of Phyllodocida (Annelida: Errantia), with a Focus on Glyceridae, Goniadidae, Nephtyidae, Polynoidae, Sphaerodoridae, Syllidae, and the Holoplanktonic Families. Divers., 13(3): 131. https://doi.org/10.3390/d13030131

Mesnil, F. and Caullery, M. (1918). Sur l'organisation et la biologie d'un Syllidien Exogone (Parexogone) hebes Webster et Benedict, var. hibernica Southern, habitant un sable compacte. Bull. de la Soci. Zool. de la France, 42: 126-132.

Mieszkowska, N.; Firth, L. and Bentley, M. (2013). Impacts of climate change on Intertidal habitats, MCCI, pp. 180-192. DOI: 10.14465/2013.arc19:180-192.

Nascimento, R. L.; Fukuda, M. V.; Paresque, K.; Nogueira, J. M. M. and de Paiva, P. C. (2021). A synopsis of Salvatoria McIntosh, 1885 (Annelida: Syllidae: Exogoninae) from Brazilian coastal and oceanic waters. PLoS ONE, 16(5): e0258022. https://doi.org/10.1371/journal.pone.0250472

Nogueira, J.M.; San Martín, G. and Amaral, A.C.Z. (2001). Description of five new species of Exogoninae Rioja, 1925 (Polychaeta: Syllidae) associated with the stony coral Mussismilia hispida (Verrill, 1868) in São Paulo State, Brazil. J. Nat. Hist., 35(12): 1773-1794.

Ørsted, A.E. (1845). Ueber die Entwicklung der Jungen bei einer Annelide und über änveren Untersuchiede zwischen beiden Geschlechtern. Arch. für Naturgesch. Berl., 11(1): 20-23.

Pamungkas, J.; Glasby, C. J.; Read, G. B.; Wilson, S. P. and Costello, M. J. (2019). Progress and perspectives in the discovery of polychaete worms (Annelida) of the world. Helgol. Mar. Res., 73(4): 1-10. doi:10.1186/s10152-019-0524-Z

Por, F. D. (1978). Lessepsian migration. The influx of Red Sea biota into the Mediterranean by way of the Suez Canal. Ecological Studies, 23. SpringerVerlag, Berlin, $228 \mathrm{pp}$.

Quatrefages, A. (1865). Histoire naturelle des annelés marins et d'eau douce. Annélides et Géphryriens. Paris 1: Librarie encyclopédique de Roret, 588 pp.

Radwan, N. A. (2014). Biological and molecular studies on selected molluscs collected from the Egyptian coastal water. Ph. D. Thesis, Faculty of Science, Suez Canal University, Egypt.194 pp. 
Read, G. and Fauchald, K. (2020). World Polychaeta database. Salvatoria McIntosh, 1885 .

Safriel, U. N. and Lipkin, Y. (1975). Patterns of colonization of the eastern Mediterranean intertidal zone by Red Sea immigrants. J. of Ecol., 63: 61-63.

San Martín, G. (1984a). Descripción de una nueva especie y revisión del género Sphaerosyllis (Polychaeta: Syllidae). Cah. de Biol. Mar., 25: 375-391.

San Martín, G. (1984b). Estudio biogeográfico, faunistico y sistemático de los poliquetos de la familia Silidos (Syllidae: Polychaeta) en Baleares. PhD Thesis, Madrid, Spain: Universidad Complutense de Madrid.

San Martín, G. (1991). Grubeosyllis and Exogone (Exogoninae, Syllidae, Polychaeta) from Cuba, the Gulf of Mexico, Florida and Puerto Rico, with a revision of Exogone. Bull. Mar. Sci., 49: 715-740.

San Martín, G. (2003). Annelida Polychaeta II: Syllidae. In: Ramos MA, editor. Fauna Ibérica. Madrid: Museo Nacional de Ciencias Naturales de Madrid CSIC, 554 pp.

San Martín, G. (2005). Exogoninae (Polychaeta, Syllidae) from Australia with the description of a new genus and twenty-two new species. Record. Austra. Mus., 57: 39152.

San Martín, G. and Aguado, M. (2014). Family: Syllidae. In: Schmidt-Raesa A, editor. Phyllodocida, Nereidiformia Handbook of Zoology, Annelida. Verlag Walter de Gruyter $\mathrm{GmbH} \&$ Co. 52 pp. In press, printed version.

Sardá, R. (1984). La subfamilia Exogoninae (Polychaeta: Syllidae) de Gibraltar, con la descripción de Pseudobrania euritmica n.sp. Public. del Depart. de Zool., Barcel., 10: 7 13.

Verrill, A. E. (1900). Additions to the Turbellaria, Nemertina, and Annelida of the Bermudas, with revisions of some New England genera and species. Trans Conne. Acad. Art. Sci., 10: 595-671. 